\title{
$\square$
}

\section{What Explains the Growth in Commodity Derivatives?}

\author{
Parantap Basu and William T. Gavin
}

\begin{abstract}
This article documents the massive increase in trading in commodity derivatives over the past decade-growth that far outstrips the growth in commodity production and the need for derivatives to hedge risk by commercial producers and users of commodities. During the past decade, many institutional portfolio managers added commodity derivatives as an asset class to their portfolios. This addition was part of a larger shift in portfolio strategy away from traditional equity investment and toward derivatives based on assets such as real estate and commodities. Institutional investors' use of commodity futures to hedge against stock market risk is a relatively recent phenomenon. Trading in commodity derivatives also increased along with the rapid expansion of trading in all derivative markets. This trading was directly related to the search for higher yields in a low interest rate environment. The growth was both in organized exchanges and over-thecounter (OTC) trading, but the gross market value of OTC trading was an order of magnitude greater. This growth is important to note because a critical factor in the recent crisis was counterparty failure in OTC trading of mortgage derivatives. (JEL G120, G130, G180)
\end{abstract}

Federal Reserve Bank of St. Louis Review, January/February 2011, 93(1), pp. 37-48.

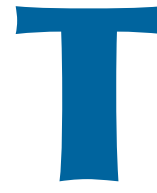

he recent financial crisis was caused by large financial firms taking on too much risk (leverage) using complicated instruments in opaque trading environments. ${ }^{1}$ Commodity derivatives trading was one such area. Commodity derivatives include futures and options traded on organized exchanges as well as the forwards and options traded over the counter. Organized exchanges monitor trading of standardized contracts and require margin accounts that protect investors against counterparty risk. The exchange is the counterparty in all trades. Over-the-counter (OTC) trades are bilateral exchanges of customized contracts. Margins are not required and such trading has

\footnotetext{
1 See remarks by Gensler (2010).
}

not been monitored. On July 21, 2010, President Obama signed the Dodd-Frank Wall Street Reform and Consumer Protection Act into law. As of this writing, the regulatory rules have yet to be finalized, but the proposed regulations are intended to limit the use of derivatives by banks and make OTC trading more transparent.

The market failure that led to the recent financial crisis was centered in the opaque, bilateral OTC trading by firms that policymakers at the Federal Reserve and the Treasury considered too big to fail. Because of the potential risks involved, it is important to understand mechanisms that large financial firms can use to exploit the government's safety net. In this article, we document the massive increase in trading in commodity derivatives over the past decade. This growth far

Parantap Basu is a professor of macroeconomics at Durham University, Durham, U.K. William T. Gavin is a vice president and economist at the Federal Reserve Bank of St. Louis. The authors thank Kevin Kliesen and Kenji Wada for helpful comments.

(C) 2011, The Federal Reserve Bank of St. Louis. The views expressed in this article are those of the author(s) and do not necessarily reflect the views of the Federal Reserve System, the Board of Governors, or the regional Federal Reserve Banks. Articles may be reprinted, reproduced, published, distributed, displayed, and transmitted in their entirety if copyright notice, author name(s), and full citation are included. Abstracts, synopses, and other derivative works may be made only with prior written permission of the Federal Reserve Bank of St. Louis. 


\section{Basu and Gavin}

outstrips the growth in commodity production and the need for derivatives to hedge risk by commercial producers and users of commodities.

During the past decade, many institutional portfolio managers added commodity derivatives as an asset class to their portfolios. This addition resulted in substantial growth in the use of commodity derivatives - growth out of proportion with the historical levels associated with commercial hedging. This shift was part of a larger change in portfolio strategy away from traditional equity investment and toward derivatives based on assets such as real estate and commodities.

Trading in derivatives does not affect the fundamentals of supply and demand in any obvious way. The derivative trades sum to zero-for every winner there is a loser, for every gain there is an equal loss. Financial firms can write an arbitrarily large number of contracts betting on a future price without necessarily affecting the level of that price. However, an arbitrarily large number of contracts means that there can be an arbitrarily large number of losers. The important policy question is whether the taxpayer is at risk for counterparty failure in OTC trading when some financial firms incur large losses. If a large portion of these investments is made by financial firms that would likely fall under the protection of the government's safety net, then the firms that win will retain their profits while those that lose may shift the burden of their losses to the taxpayer. There is a public interest in preventing large-scale betting by institutions protected by the government's safety net. It is not a zero-sum game for the taxpayer.

In this article, we explore the reasons for the explosive growth in trading in commodity derivatives and advance two main reasons for that growth. First, investors used commodity futures to hedge against equity risk. Both academic and industry economists argued that a negative correlation between returns on equity and commodity futures offered an unexploited hedging opportunity in using commodity derivatives as an asset class.

Second, trading in commodity derivatives increased along with the rapid expansion of trading in all derivative markets. This trading was directly related to the search for higher yields in a low interest rate environment. The search for higher yields refers to the tendency of both individual and institutional investors to choose riskier assets when the return on safe assets is low. ${ }^{2}$ Jiménez et al. (2008) used a large dataset from the credit register in Spain to show that bank borrowers are more likely to default if the loans are made when central bank interest rates are relatively low. They also showed that (i) the price of risk tends to be low when short-term interest rates are low and (ii) if the interest rate is low for a long time, the economy's "portfolio" of loans tends to be riskier.

Many derivative instruments that grew rapidly after 2000, such as commodity futures index funds and derivatives on mortgage-backed securities (MBS) such as collateralized debt obligations, were developed in the 1980s and 1990s. Dybvig and Marshall (1997) described the newly developed risk-management processes that included ever more-complex derivatives. Their description noted the possibility of the good, the bad, and the ugly outcomes of using such financial instruments. The good is the new opportunity for moreprecise hedging and risk reduction. ${ }^{3}$ The bad is the possibility that CEOs and portfolio managers may not fully understand the ramifications of using these complex new instruments. The ugly is the possibility that firms could use OTC derivatives to intentionally take risks that could not be observed by regulators or other market participants. All three outcomes have been evident over the past decade, but it is the ugly outcome that is most responsible for the worldwide financial crisis.

The paper is organized as follows. The second section documents some facts about growth in commodity futures and provides indirect evidence that the rise in derivatives trading was associated with institutional investors using commodity derivatives as an asset class. The third section advances arguments why a negative correlation

\footnotetext{
2 See, for example, Rajan (2005), Ferguson et al. (2007), and Gerlach et al. (2009).

3 See Banerji and Basu (2009) for an example showing how banks could use new and creative contracts to offer new risk-bearing services that would be expected to reduce the risk premium in equity markets.
} 
between stock and futures returns may not necessarily offer a hedging opportunity to investors. The concluding section discusses the reform legislation and prospects for continued trading in commodity derivatives.

\section{TRADING IN COMMODITY DERIVATIVES: THE FACTS}

The large increase in trading in commodity derivatives was not due to a large increase in hedging by commercial users. It is important to distinguish between the commercial hedgers who produce and use commodities and the institutional investors who use commodity futures to hedge equity and bond risk. For example, commodity futures index funds were marketed to institutional investors as an asset class. Figure 1A depicts the growth of these funds using year-end data for 1994 to 2008. Contracts for these funds are an investment in a long position in a valueweighted portfolio of commodity futures. In 2002, there were fewer than $\$ 20$ billion in these indexfund contracts. At year-end 2008 these funds had grown to more than $\$ 250$ billion, about one-fourth to one-third of the notional amounts of commodity futures traded on organized exchanges. In 2007 the Commodity Futures Trading Commission (CFTC) began collecting information on the amount of funds invested in these index funds. Figure 1B reports the CFTC data through September 2010. Note that the exchange trading of commodity futures has rebounded and has nearly recovered to the peak achieved in June of 2008.

Trading in OTC commodity derivatives markets also grew rapidly during the period, as shown by the gross market value of commodity derivatives (Figure 2A). Gross market value is a measure of the funds that investors have at risk on both sides of the bet; for example, it includes funds at risk on both the long and short sides of a forward contract. Figure 2A also depicts the gross market value of equity derivatives contracts. The gross market value of commodity derivatives rose by a factor of 25 between June 2003 and June 2008reaching $\$ 2.13$ trillion in June 2008. Figure 2B shows the gross market values of commodity derivatives (excluding precious metals) and gold derivatives. ${ }^{4}$ Traditionally, institutional investors have used gold as a hedge against inflation and other risks. There was no surge in the volume of gold derivatives as there was for other commodities.

Figure 3 shows prices for the Standard and Poor's (S\&P) Goldman Sachs Commodity Index (GSCI), gold, and two ABX indexes that are for derivatives on insurance contracts for MBS. ${ }^{5}$ From the day the S\&P GSCI peaked, July 3, 2008, to the day Lehman Brothers filed bankruptcy, September 15, 2008, the S\&P GSCI price index fell 37 percent (Figure 3). ${ }^{6}$ Investors with a short position made large profits, but investors with a long position lost hundreds of billions of dollars. These were investments traded over the counter, so it is difficult to know what part, if any, these losses played in the financial panic that accompanied Lehman's default.

Oil was about 40 percent of the weight in the S\&P GSCI and drove the broad pattern in the S\&P GSCI. The commodity price index (see Figure 3) rose very sharply with the trading volume of the commodity derivatives market (see Figures 2A and $2 \mathrm{~B}$ ) and peaked in July 2008 when oil prices peaked. It then fell sharply through the second half of 2008. The gold price was much less volatile (see Figure 3), with no unusual rise in the trading volume of gold derivatives (see Figure 2B). Note that the gold price and the commodity price index rose together until mid-March 2008 (see Figure 3), when the Federal Reserve rescued the counterparties to Bear Stearns. The commodity price index (see Figure 3 ) and trading volume of commodity derivatives then grew very rapidly while the trading volume of gold derivatives was flat to down a bit (see Figure 2B). The commodity price index started falling 10 weeks before financial markets panicked with the Lehman bank-

4 Non-gold precious metals were a small percentage relative to gold and are ignored here.

5 The gold price is a monthly average of the London PM fix; the source for all prices is Haver Analytics.

6 We assume that the S\&P GSCI represents the market price for the underlying asset in the OTC commodity contracts. 
Figure 1A

Commodity Index-Fund Investment (year-end)



NOTE: 2008 data are through March only.

SOURCE: Masters (2008, Chart 1).

Figure 1B

Notional Long Positions Invested in Commodity Futures Index Funds



SOURCE: CFTC. 


\section{Figure 2A}

\section{OTC Trading in Commodity and Equity Derivatives (gross market value)}

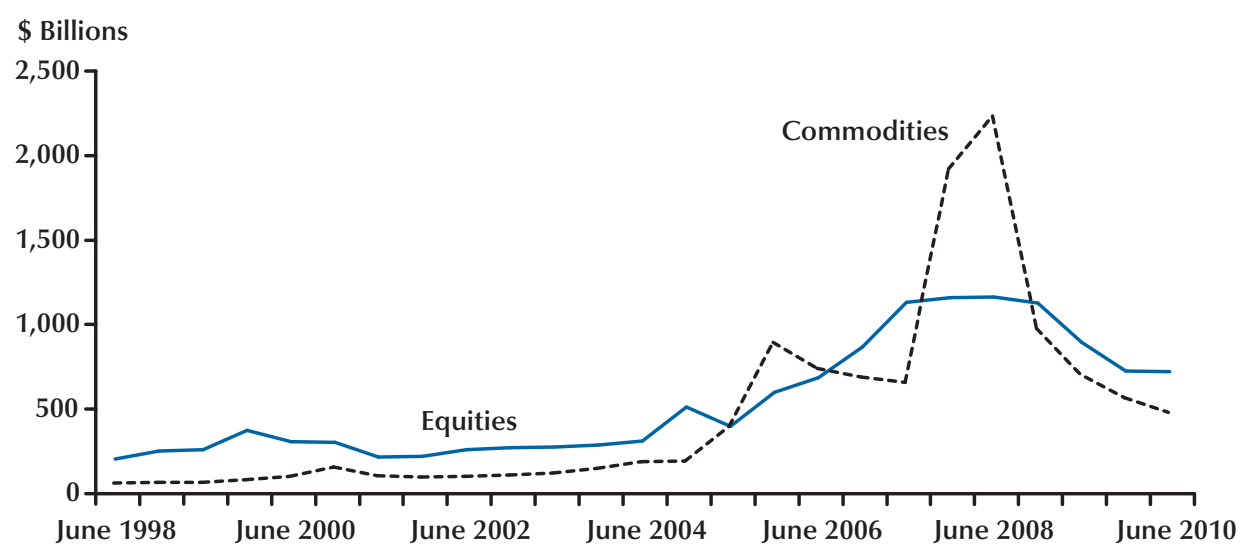

SOURCE: Bank for International Settlements derivatives statistics.

\section{Figure 2B}

\section{OTC Trading in Commodity Derivatives (gross market value)}

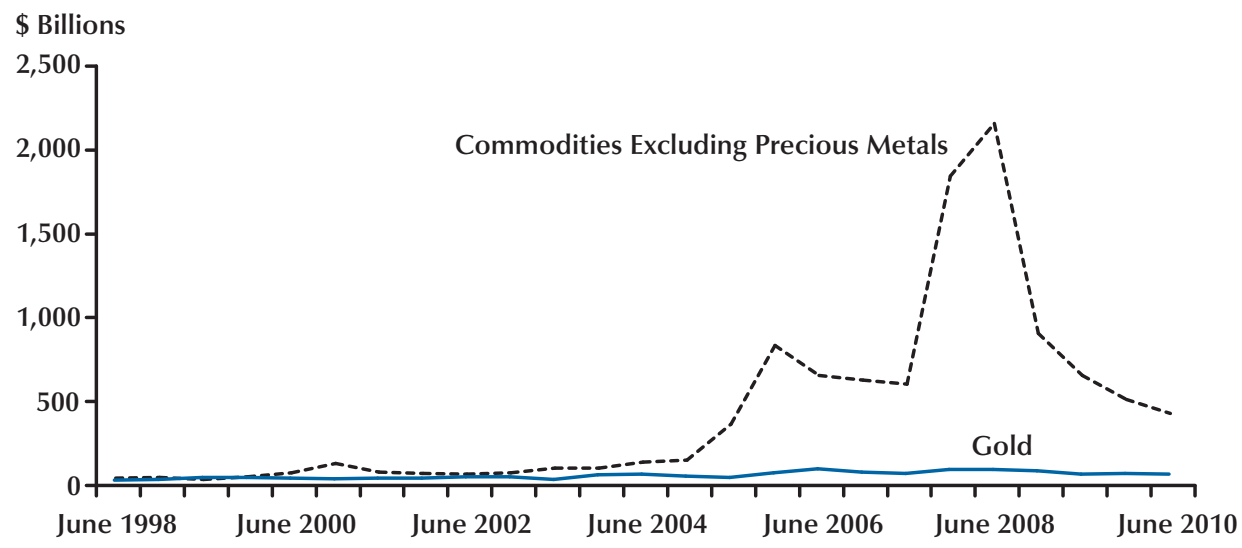

SOURCE: Bank for International Settlements derivatives statistics. 
Figure 3

\section{Prices on Commodities and ABX Contracts}



NOTE: The gold index and the S\&P GSCI are each equal to 100 on January 19, 2007. The indexes for the price of $A B X$ contracts are equal to 100 when they are launched. AAA and BBB- are the highest- and lowest-rated mortgage derivatives, respectively. The ABXHE-BBB- 06-2 is an index for the value of mortgage loan insurance derivatives on the riskiest of the subprime mortgages originated before the second half of 2006. The launch date for an index depends on when the underlying mortgages were originated; the 06-2 index was launched on July 19, 2006, and the 07-1 index on January 19, 2007.

SOURCE: Haver Analytics.

ruptcy filing. The fourth quarter of 2008 was very bad for the economy and financial markets. After year-end, the prices of gold and other commodities as measured by the S\&P GSCI began an upward trend that continued through to December 2010.

It is possible that the unusual spike in prices and trading volume for commodity futures was influenced by the loss of confidence in MBS and associated derivatives. Figure 3 shows the loss of confidence in both the highest-rated (AAA) and lowest-rated (BBB-) mortgage derivatives. The $\mathrm{ABX} \mathrm{BBB}-$ index - for derivatives on mortgage insurance for subprime MBS—began to decline in December 2006 and had fallen 60 percent by August 2007 when the possibility of a wider financial crisis became apparent. By that time, confidence in the highest-rated mortgage paper was also falling. The prices and trading volume of commodity derivatives rose sharply as confidence in the market for subprime mortgages collapsed.

The sharp spike in the price of commodity futures in July 2008 and subsequent collapse by the end of that year is hard to explain. The S\&P GSCI was driven mainly by oil prices. Although the longer-term rise in oil prices is often attributed to rising demand associated with growth 


\section{Figure 4}

\section{OTC Trading in Derivatives (notional amounts)}

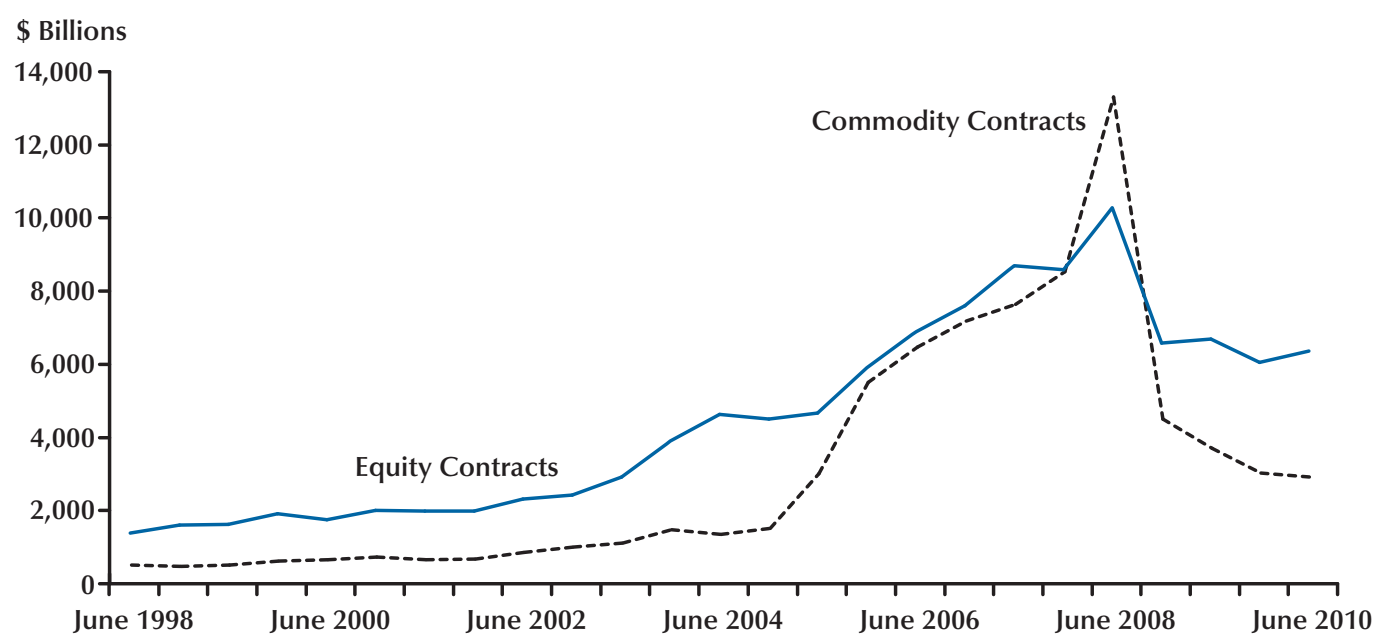

SOURCE: Bank for International Settlements derivatives statistics.

in emerging market economies, a secular rise in demand cannot explain the 2008 boom and bust. $^{7}$

Figure 4 shows the outstanding notional amounts of commodity derivatives contracts (their face value): The amount tripled between June 1998 and June 2003 and then rose 19-fold in the next 5 years, peaking at $\$ 13$ trillion in June 2008. During this period, trading in commodity derivatives grew to exceed trading in equity derivatives. Note that, in contrast to trading on organized exchanges, OTC trading in commodity derivatives has continued to decline since the summer of 2008.

To provide some perspective on the size of derivative positions, consider that world GDP rose from $\$ 30$ trillion in 1998 to $\$ 61.1$ trillion in 2008. ${ }^{8}$ Commodity prices almost quadrupled over the decade before their peak in July 2008. Even at 2008 prices, the total output of commodities was less than half the notional value of outstanding commodity derivatives contracts

\footnotetext{
7 See, for example, Kilian (2009).

8 We are using World Bank estimates of world gross domestic product (GDP) in U.S. dollars.
}

(nearly $\$ 13$ trillion). ${ }^{9}$ The ratio of the notional amount of commodity derivatives contracts in June 1998 to world GDP rose from 1.5 percent in 1998 to 21.6 percent in 2008. Over the same period, the ratio of equity derivatives to world GDP rose from 4.2 percent to 16.7. At first glance, this shift appears to be consistent with the rising use of commodity derivatives as an asset class in institutional portfolios.

\section{TWO EXPLANATIONS FOR THE RISE IN COMMODITY DERIVATIVES TRADING}

One explanation for the rise in commodity derivatives trading is that it was simply part of a widespread increase in risky investing during the past decade that was attributed to a "search for yield." A second explanation for the rise is

9 Even at its peak price in July 2008, total world production of oil in 2008 was less than $\$ 4.5$ trillion. Oil constitutes the largest share of total commodity production. For example, the estimated worldwide production of corn, wheat, and soybeans in 2009 was less than $\$ 100$ billion. See, for example, www.nue.okstate.edu/Crop Information/World Wheat Production.htm. 


\section{Basu and Gavin}

that it was driven by a mistaken notion that an investment in commodity futures can be used to hedge equity risk. An early paper by Greer (2000) and later papers by Erb and Harvey (2006) and Gorton and Rouwenhorst (2006) found a negative correlation between returns to a passive long investment in commodity futures and returns to equity.

\section{The Search for Yield Hypothesis}

The term "search for yield" is somewhat vague. In an efficient market model, all investors are assumed to optimize over combinations of risk and return. One should not choose more risk unless the expected returns also rise. One way to interpret the search for yield is to argue that, at low interest rates, investors are willing to take on relatively more risk for only small increases in return. In such a case, investors will bid up the price of risky assets and, all else equal (including default probabilities), the price of risk will decline. This search for yield may explain why risk premiums were so low in 2003 and 2004 and offers one reason (among many) for the high leverage in household mortgages and financial institutions.

During the period of rapid growth in commodity derivatives, managers of pension funds, university endowment funds, and other institutional funds began to include commodity derivatives as an asset class in their portfolios. There was a shift out of domestic equities into commodities. ${ }^{10}$ One argument was that investing in such real assets could increase returns without adding much risk. This leads us to the second hypothesis: Brokers and dealers selling commodity derivatives also argued that commodity futures could be used to hedge equity risk.

\section{Hedging Hypothesis}

Fully collateralized commodity futures historically have offered the same return and Sharpe ratio as U.S. equities. Although the risk premium on commodity futures is essentially the same as that on equities for the study period, commodity futures returns are negatively cor-

${ }^{10}$ See Cohn and Symonds (2004), Symonds (2004), and Palmeri (2006). related with equity returns and bond returns. The negative correlation is the result, primarily, of commodity futures' different behavior over a business cycle (Gorton and Rouwenhorst, 2006, p. 47).

While the use of commodities to hedge inflation risk was widely appreciated, their use to hedge equity or business cycle risk is more controversial. Using data from July 1959 to December 2004, Gorton and Rouwenhorst (2006) calculated the return to holding a rolling long investment in a value-weighted portfolio of commodity futures. They reported that the correlation was nearly zero for short horizons and negative, but not statistically significant, for horizons up to one year. This is consistent with research at the CFTC by Büyükşahin, Haigh, and Robe (2008), who found that the unconditional correlation between equity and commodity futures returns is near zero. But their results changed as the investment horizon lengthened. Gorton and Rouwenhorst (2006) also reported that if this investment was rolled-over for a longer period, the return was negatively correlated with the returns from comparable bond and equity portfolios. They found that the average correlation between returns on equities and commodity futures was a statistically significant -0.42 if the investments were held for 5 years.

Figure 5 reports a rolling 5 -year correlation between returns on an index of S\&P 500 equities and the index of commodities included in the S\&P GSCI. When commodity prices peak in June 2008 , the correlation is negative on average. However, following the collapse of commodity prices in the summer of 2008 and the subsequent financial panic in September 2008, the correlation becomes highly positive, reaching a record 0.56 in February 2010. Thus, portfolios that included commodity derivatives to hedge equity risk did very badly over the last 2 two years studied. In the years building up to the crisis and since, portfolios that included commodity derivatives were more volatile than equities-only portfolios. The high returns in 2004 through 2006 reflected very risky investments-not only those in mortgage derivatives. Note that this is the first business cycle following the widespread adoption of this new investment strategy. 


\section{Figure 5}

\section{Rolling Correlation Coefficient Between Daily Equity and Commodity Returns (5-year window with 5-year returns)}

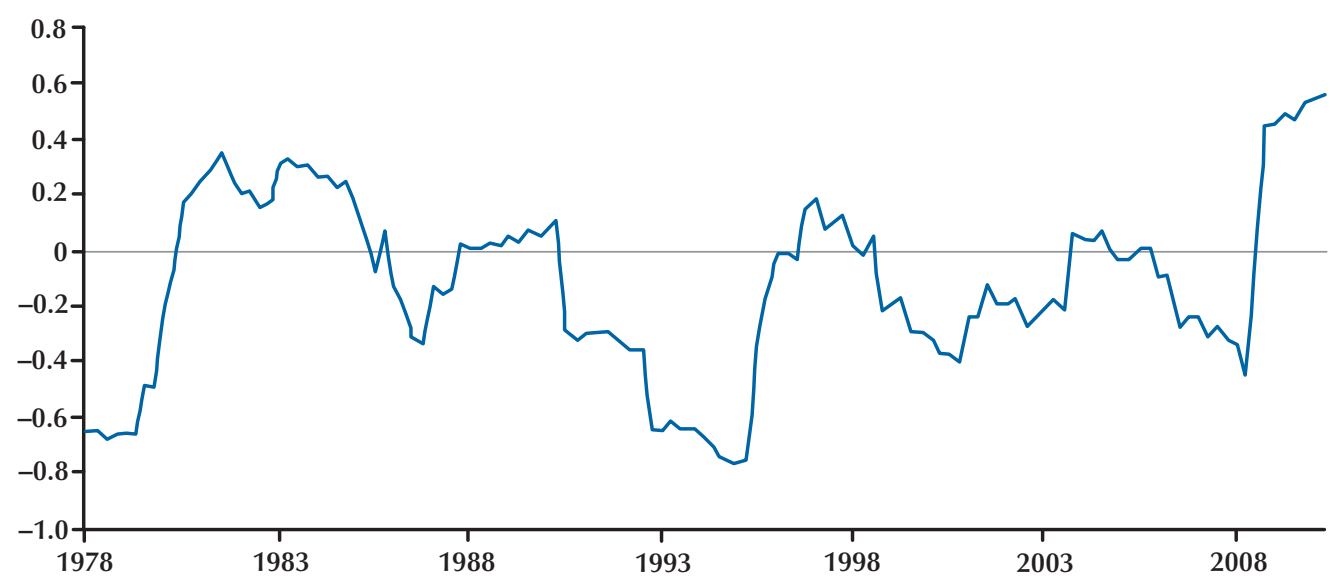

NOTE: The equity index is the S\&P 500. The commodity index is the S\&P GCSI. The returns are calculated as the percent change in the total return.

SOURCE: Haver Analytics and authors' calculations.

\section{Figure 6}

\section{Rolling Correlation Coefficient Between Daily Equity and Commodity Returns (1-year window)}

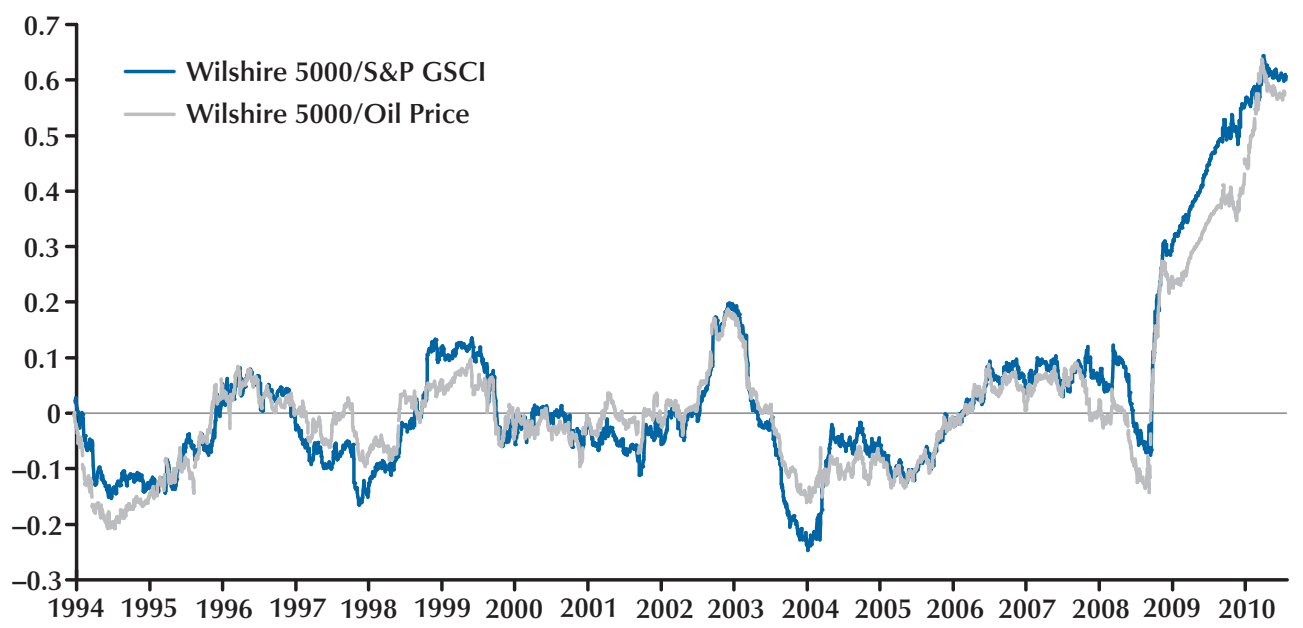

NOTE: The equity index is the Wilshire 5000. The commodity index is the S\&P GCSI. The oil price is the domestic spot price on West Texas Intermediate crude oil.

SOURCE: Haver Analytics and authors' calculations. 


\section{Basu and Gavin}

Similar changes are seen in the correlation of daily returns. Figure 6 reports a rolling correlation coefficient between total returns to investments in the Wilshire 5000 and the S\&P GSCI using a 1-year window. The correlation is relatively small and generally not significantly different from zero until the onset of the financial crisis. During and following the crisis, the correlation is very large and positive. Because the S\&P GSCI is heavily weighted in oil, we also show the daily correlation between the Wilshire 5000 and the daily spot price of West Texas Intermediate crude oil. This correlation makes it clear that the S\&P GSCI is heavily influenced by the oil market. ${ }^{11}$

Erb and Harvey (2006) argued that the most important source of expected return from a portfolio of commodity futures comes from diversification across individual commodities that have uncorrelated returns. They described the different schemes used to construct weights to aggregate the component commodities and explained why the excess returns depend on there being little correlation among returns for the individual component commodities. They also warned against assuming that historical return correlations will persist. Tang and Xiong (2010) showed that the introduction of index trading led to a rise in the correlation among the individual commodities included in an index, thus reducing or even eliminating the gains to diversification within individual index funds. They further showed that the rise in the correlations among the individual components began in 2004, well before the onset of the crisis, and became higher over the next few years as open interest in commodity index futures rose.

Figures 5 and 6 show that the correlation between returns to equity and commodity futures can change sign over time. In a general equilibrium model in which there are no unexploited hedging opportunities, it is straightforward to show that the equilibrium correlation can be

\footnotetext{
11 Table 3 in Erb and Harvey (2006) reports the portfolio weights for three commodity futures indexes as of May 2004. Crude oil is about 40 percent of the S\&P GSCI and all energy commodities make up two-thirds of the weight in the index. This does not include grains used for ethanol. They also report that 86 percent of the open interest in commodity futures indexes was in the S\&P GSCI.
}

either negative or positive, depending on the nature of shocks to the world economy. ${ }^{12}$ In particular, the correlations shown in Figures 5 and 6 depend on investors' perceptions about how the domestic economy and commodity production will respond to various shocks.

\section{CONCLUSION}

We offer two possible explanations for the surge in trading commodity derivatives. The first also explains the massive increase in trading of risky mortgage debt and all financial derivatives: Investors were searching for more substantial yields in an environment with very low returns paid on safe assets. This also explains why investors moved from real estate derivatives to commodity derivatives when the problems in the subprime market became apparent.

The second reason is a prevailing notion among institutional investors that commodity derivatives are an asset class that can be used to hedge equity risk, a notion we argue is mistaken. Even if the observed correlation between equity and commodity futures returns were reliably negative, it is likely that this negative correlation would be an equilibrium arbitrage phenomenon that should be expected in a world where no unexploited hedging profit opportunity exists. The rise in commodity derivative trading thus poses a challenge to asset-pricing theorists to explain in a well-articulated rational asset pricing model.

The lesson from this financial crisis is not that the government should prevent firms and investment funds from investing in commodity futures. As we noted, it was the unregulated, opaque OTC trading that was a critical factor in the financial crisis. The Dodd-Frank Act is intended to limit this type of trading and to make it more transparent. This outcome is already suggested by the incoming data. On organized exchanges (where traders are monitored and protected against counterparty failure), trading of commodity derivatives has nearly recovered

\footnotetext{
${ }^{12}$ See, for example, Basu and Gavin (2010).
} 
to the peak achieved in June of 2008, while OTC trading in commodity derivatives has continued to decline.

A lesson from the crisis is that regulators and policymakers should monitor financial innovations closely to learn whether they are being used to take excessive risks- that is, risks firms would not take if they were operating outside the government's safety net. Under new regulations, the CFTC will collect information that should make trading in commodity derivatives more transparent. Banks argue that they need to use commodity derivatives to help customers manage risks. This may be true, but the recent experience in commodity futures did not reduce risks but exacerbated them just at the wrong time. The challenge to the government is to prevent too-big-to-fail firms from using current and yet invented derivatives to increase overall risk in the financial system.

\section{REFERENCES}

Banerji, Sanjay and Basu, Parantap. "Universal Banking and the Equity Risk Premium.” Unpublished manuscript, Durham University, November 2010.

Basu, Parantap and Gavin, William T. "Negative Correlation between Stock and Futures Returns: An Unexploited Hedging Opportunity?” Unpublished manuscript, Federal Reserve Bank of St. Louis, December 2010.

Büyüks, ahin, Bahattin; Haigh, Michael S. and Robe, Michel A. "Commodities and Equities: A 'Market of One'?” Working paper, Commodity Futures Trading Commission, June 9, 2008; ww.cftc.gov/ucm/groups/public/@aboutcftc/documents/file/amarketofone update0608.pdf.

Cohn, Laura and Symonds, William C. "Striking Gold in Commodities.” Business Week, October $25,2004$.

Dybvig, Philip H. and Marshall, William J. “The New Risk Management: The Good, the Bad, and the Ugly.” Federal Reserve Bank of St. Louis Review, November/December 1997, 79(6) pp. 9-22; http://research.stlouisfed.org/publications/review/97/11/9711pd.pdf.

Erb, Claude B. and Harvey, Campbell R. “The Strategic and Tactical Value of Commodity Futures.” Financial Analysts Journal, March/April 2006, 62(2), pp. 69-97.

Ferguson, Roger W. Jr.; Hartmann, Philip; Panetta, Fabio and Portes, Richard. Geneva Report on the World Economy 9: International Financial Stability. Geneva, Switzerland: Centre for Economic Policy Research and the International Center for Monetary and Banking Studies, 2007.

Gensler, Gary. "Remarks.” Presented at the Sandler O’Neill Global Exchange and Brokerage Conference, New York, June 3, 2010; www.cftc.gov/pressroom/speechestestimony/opagensler-46.html.

Gerlach, Stefan; Giovannini, Alberto; Tille, Cédric and Viñals, José. Geneva Reports on the World Economy 10: Are the Golden Years of Central Banking Over? The Crisis and the Challenges. Geneva, Switzerland: Centre for Economic Policy Research and the International Centre and the International Center for Monetary and Banking Studies, 2009.

Gorton, Gary and Rouwenhorst, K. Geert. "Facts and Fantasies about Commodity Futures.” Financial Analysts Journal, March/April 2006, 62(2), pp. 47-68.

Greer, Robert J. “The Nature of Commodity Index Returns.” Journal of Alternative Investments, Summer 2000, 3(1), pp. 45-53. 


\section{Basu and Gavin}

Jiménez, Gabriel; Ongena, Steven; Peydró, José-Luis and Saurina, Jesús. "Hazardous Times for Monetary Policy: What Do Twenty-Three Million Bank Loans Say about the Effects of Monetary Policy on Credit Risk-Taking?" Working Paper No. 0833, Bank of Spain, 2008; www.bde.es/webbde/SES/Secciones/Publicaciones/

PublicacionesSeriadas/DocumentosTrabajo/08/Fic/dt0833e.pdf.

Kilian, Lutz. "Not All Oil Price Shocks Are Alike: Disentangling Demand and Supply Shocks in the Crude Oil Market." American Economic Review, June 2009, 99(3) pp. 1053-69.

Masters, Michael W. Testimony before the Committee on Homeland Security and Governmental Affairs. United States Senate, May 20, 2008; http://hsgac.senate.gov/public/ files/052008Masters.pdf.

Palmeri, Christopher. "CalPERS' New Crusade: Commodities Are Where the Hefty Returns Are, Says Investment Chief Russell Read.” BusinessWeek, June 5, 2006; www.businessweek.com/print/magazine/content/06 23/b3987080.htm?chan=gl.

Rajan, Raghuram G. "Has Financial Development Made the World Riskier?” in The Greenspan Era: Lessons for the Future. Proceedings of the symposium sponsored by the Federal Reserve Bank of Kansas City, Jackson Hole, Wyoming, August 25-27, 2005. Kansas City, MO: Federal Reserve Bank of Kansas City, 2005, pp. 313-67; www.kansascityfed.org/publicat/sympos/2005/pdf/Rajan2005.pdf.

Symonds, William C. "How to Invest Like Harvard.” BusinessWeek, December 27, 2004.

Tang, Ke and Xiong, Wei. “Index Investment and the Financialization of Commodities.” Working paper, Princeton University, August 2010; www.princeton.edu/ wxiong/papers/commodity.pdf. 